\title{
RANCANGAN DISTRIBUSI LPG 3 KG BERDASARKAN KEBIJAKAN DISTRIBUSI SISTEM TERTUTUP DI WILAYAH PEMASARAN KOTA BANDUNG
}

\author{
Sofiani Nalwin Nurbani* \\ Prodi Teknik Industri, Fakultas Teknik, Universitas Sangga Buana Bandung \\ Jl. PHH Mustofa NO. 68, Bandung 40124
}

(Received: March 2, 2018/Accepted: November 21, 2019)

\begin{abstract}
Abstrak
Pada tahun 2007 Pemerintah mulai melakukan konversi dari minyak tanah ke LPG $3 \mathrm{~kg}$. Untuk mengatasi kelangkaan LPG $3 \mathrm{~kg}$, Pertamina dan Pemerintah mulai melakukan perbaikan yang salah satunya adalah merubah sistem distribusi LPG 3 kg yang awalnya distribusi Sistem Terbuka menjadi distribusi Sistem Tertutup. Optimasi distribusi LPG $3 \mathrm{~kg}$ dengan sistem terbuka dan sistem tertutup dilakukan dengan menggunakan metode Transportasi dengan linear programming. Perhitungan optimasi maka perhitungan dilakukan dengan bantuan software excel Analytic Solver Platform, sehingga didapatkan bahwa Ongkos Transportasi LPG $3 \mathrm{~kg}$ berdasarkan Sistem Terbuka sebesar Rp.8.319.765.767,07 sedangkan untuk Sistem Tertutup sebesar Rp.8.724.410.280,30. Hasil akhir pengelompokan coverage area SPPBE berdasarkan sistem tertutup adalah SPPBE 1 memiliki wilayah pemasaran sejumlah 12 Agen dengan kapasitas SPPBE yang terpakai sebesar 867.473 tabung per bulan. SPPBE 2 memiliki wilayah pemasaran sejumlah 12 Agen dengan kapasitas SPPBE 2 yang terpakai yaitu sebesar 1.053 .607 tabung per bulan. SPPBE 4 memiliki wilayah pemasaran sebanyak 7 Agen dengan kapasitas yang terpakai yaitu sebesar sebesar 802.747 tabung per bulan. Penelitian secara kualitatif dilakukan bertujuan untuk mengetahui kriteria-kriteria yang dibutuhkan dalam menentukan lokasi pendirian SPPBE baru. Perhitungan berdasarkan metode AHP dilakukan dengan software expertchoise. Hasil akhir pengukuran metode AHP diperoleh bahwa alternatif lokasi yang memiliki prioritas tertinggi adalah wilayah Kecamatan Gedebage.
\end{abstract}

Kata Kunci: distribusi sistem tertutup; linear programming; software excel Analytic Solver Platform

\begin{abstract}
[3kg LPG Distribution Design Based On Closed System Distribution Policy In The Marketing Area Of Bandung City] In 2007 the Government started to convert from kerosene to LPG $3 \mathrm{~kg}$. To overcome the scarcity of LPG $3 \mathrm{~kg}$, Pertamina and Government started to make improvements which one of them is to change the distribution system of LPG $3 \mathrm{~kg}$ which initially the Open Systems distribution into the distribution of Closed Systems. Optimization of $3 \mathrm{~kg} L P G$ distribution with open system and closed system is done by using Transportation method with linear programming. To simplify the calculation of optimization, the calculation is done with the help of software excel Analytic Solver Platform, so it is found that $3 \mathrm{~kg}$ LPG Transportation Costs based on Open System Rp.8.319.765.767,07 while for Closed System Rp.8.724.410.280,30. The final result of SPPBE coverage area coverage based on closed system is SPPBE 1 has marketing area of 12 Agent with SPPBE capacity which is used is 867.473 tubes per month. SPPBE 2 has a marketing area of 12 Agents with SPPBE 2 capacity of 1,053,607 tubes per month. And SPPBE 4 has a marketing area of 7 Agents with SPPBE 4 capacity used, which amounted to 802,747 tubes per month. The qualitative research is aimed to find out the criteria needed to determine the location of new SPPBE establishment. Calculations based on the AHP method are performed with the help of expert choise software. Based on the final result of measurement of AHP method, it is found that the location alternative that has the highest priority is Gedebage sub-district.
\end{abstract}

${ }^{*}$ Penulis Korespondensi.

E-mail: sofiani.nalwin@usbypkp.ac.id/sofianinalwinnurbani@gmail.com
Keywords: loseloop distribution; linear 


\section{Pendahuluan}

Elpiji merupakan salah satu produk andalan PT. Pertamina untuk bahan bakar rumah tangga maupun usaha kecil, usaha menengah dan usaha besar yang berbentuk LPG (Liquefied Petroleum Gas). Pada tahun 2009 pemerintah mengeluarkan ketentuan mengenai produksi dan distribusi LPG $3 \mathrm{Kg}$ yang telah diatur oleh Pemerintah dalam hal ini Kementrian ESDM melalui Permen Nomor 26 Tahun 2009 Tentang Penyediaan dan Pendistribusian Liquefied Petroleum Gas. Peraturan tersebut mengartikan bahwa sistem distribusi LPG $3 \mathrm{~kg}$ mengalami perubahan sistem dari sistem distribusi terbuka (open system) menjadi sistem distribusi tertutup (closed system).

Sistem distribusi terbuka (open system) diartikan bahwa pangkalan/sub agen boleh mengambil LPG dari sejumlah agen mana saja, bahkan pengecer bisa mengambil LPG langsung ke sejumlah agen dan agen boleh mengambil LPG dari SPPBE mana saja. Sedangkan distribusi tertutup (closed system) diartikan bahwa suatu sistem distribusi yang diterapkan untuk pengisian LPG di mana Agen LPG di satu wilayah hanya bisa mengisi LPG di stasiun (SPPBE) yang ada di wilayah itu. Mereka juga hanya diperbolehkan mendistribusikan LPG di wilayah yang sudah ditetapkan.
Bandung Raya merupakan salah satu wilayah metropolitan yang meliputi: Kota Bandung, Kabupaten Bandung, Kabupaten Bandung Barat dan Kota Cimahi. Kota Bandung merupakan Ibukota Propinsi Jawa Barat. Kota Bandung terdiri atas 30 Kecamatan dan 151 Kelurahan dengan jumlah penduduk sebanyak 2.483.977 jiwa.

SPPBE yang tersebar di Wilayah Metropolitan Bandung terdapat 31 SPPBE yang tersebar di setiap Wilayah Metropolitan Bandung. Dari gambar dapat dilihat bahwa SPBE yang ada di wilayah Bandung Kota ada 6 (enam) SPPBE yaitu Patra Trading Depot Ujung Berung, PT. Limagas Jaya Mandiri, PT. Purnatarum Murni Rahayu 1, Patra Ujung Berung, PT. Mandalagiri Kaya Raya, dan PT. Purnatarum Murni Rahayu 2.

Dari hasil pengamatan maka diperlukan sebuah rancangan distribusi LPG $3 \mathrm{~kg}$ jika sistem tertutup diterapkan di wilayah Kota Bandung. Serta kebutuhan akan SPPBE yang dikarenakan oleh permintaan LPG $3 \mathrm{~kg}$ yang selalu mengalami peningkatan tiap tahunnya. Beberapa hal yang mengakibatkan peningkatan permintaan akan LPG $3 \mathrm{~kg}$ di antaranya adalah: (Siagian, 2014),

1. Ekspansi penggunaan LPG $12 \mathrm{~kg}$ ke LPG $3 \mathrm{~kg}$ akibat dari kenaikan harga LPG $12 \mathrm{~kg}$,

2. Meningkatnya usaha kecil dan menengah pengguna LPG $3 \mathrm{~kg}$,

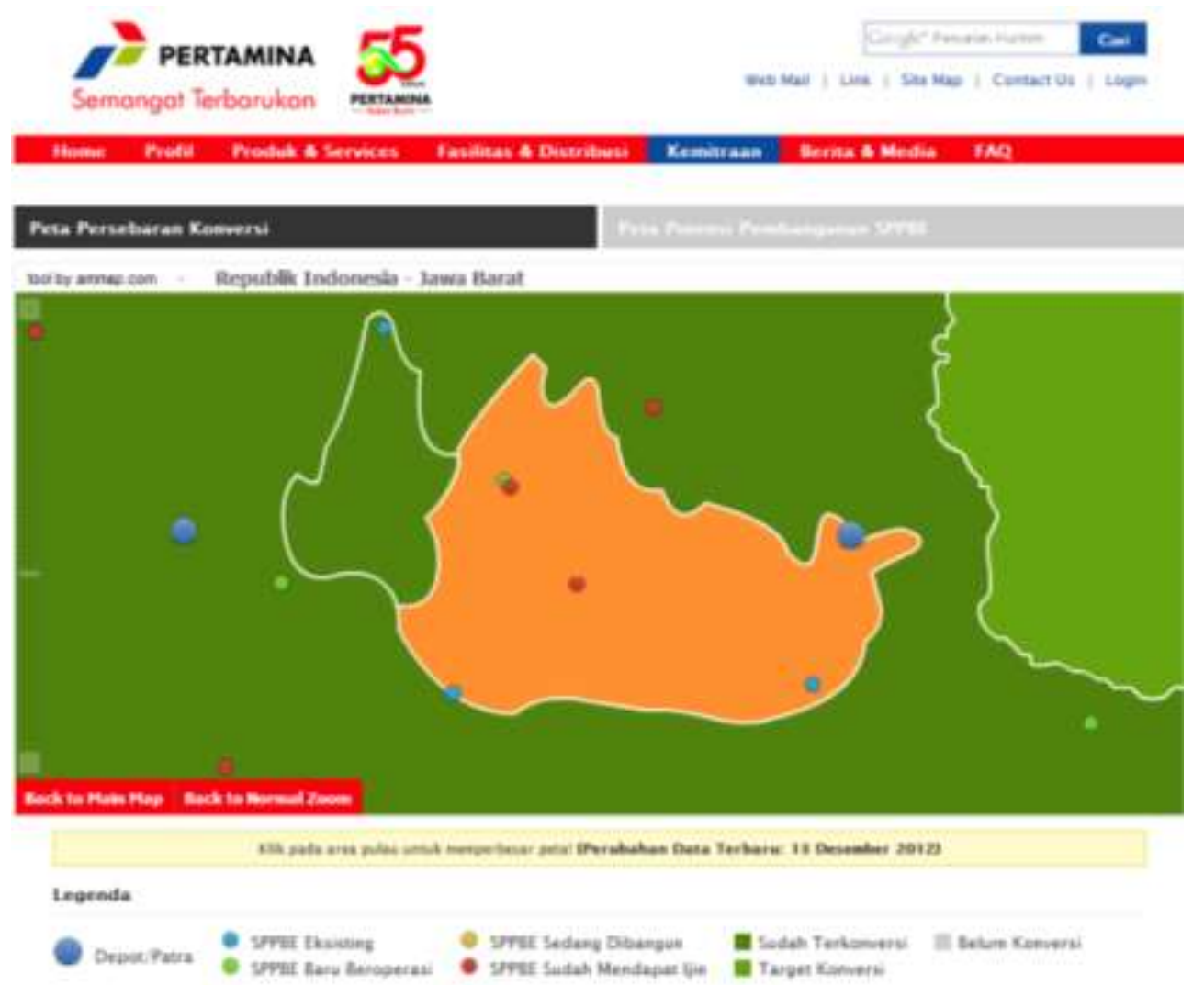

Gambar 1 Peta Lokasi Penyebaran SPPBE untuk Wilayah Bandung Kota 
3. Banyaknya warga berkategori mampu tetapi memakai gas ukuran $3 \mathrm{~kg}$,

4. Restoran maupun hotel yang menggunakan gas ukuran $3 \mathrm{~kg}$.

Berdasarkan data penelitian ESDM, bahwa kebutuhan akan gas bumi akan mengalami peningkatan dari tahun ke tahun. Di mana kebutuhan akan gas bumi untuk tahun 2015-2020 akan meningkat sebesar $6 \%$ per tahun. Sedangkan pada tahun 20202025 kebutuhan akan gas bumi meningkat sebesar 7\% dan pada tahun 2025-2030 meningkat sebesar 5\% pertahun. (Berita ESDM, 2014).

Hal tersebut menandakan terjadinya peningkatan permintaan akan gas LPG $3 \mathrm{~kg}$ setiap tahunnya, oleh karena itu perlu dilakukan analisis penerapan sistem terbuka dan tertutup dalam pemsaran LPG $3 \mathrm{~kg}$ yang akan diterapkan oleh Pertamina.

\subsection{Tujuan Penelitian}

Sehubungan dengan tujuan dari distribusi LPG $3 \mathrm{~kg}$ adalah terpenuhinya permintaan akan LPG $3 \mathrm{~kg}$ di setiap tempat yang ada di Bandung, maka tujuan dari penelitian ini adalah sebagai berikut:

1. Mengidentifikasi wilayah pemasaran (coverage area) untuk setiap SPPBE di Kota Bandung,

2. Menghitung biaya distribusi LPG $3 \mathrm{~kg}$ berdasarkan sistem tertutup,

3. Menentukan perkiraan lokasi alternatif SPPBE baru berdasarkan perkiraan permintaan sampai tahun 2030 .

\subsection{Pembatasan Dan Asumsi Penelitian}

Untuk mencari solusi dari suatu permasalahan maka diperlukannya batasan serta asumsi, dengan tujuan agar dapat memberikan arah serta proses penyelesaian masalah. Pembatasan dalam penelitian ini di antaranya adalah :

1) Penelitian hanya dilakukan dari SPPBE, Agen dan Konsumen (demand point),

2) Konsumen (demand point) yang digunakan berdasarkan wilayah Kelurahan,

3) Data jumlah penduduk diambil dari BPS (Badan Pusat Statistik) dari data Bandung Dalam Angka tahun 2014,

4) Demand point SPPBE berdasarkan jumlah Kepala Keluarga (KK) per Kelurahan.

5) Perancangan tidak memperhatikan alat transportasi (truck/pickup) yang digunakan dalam mengangkut LPG dari SPPBE ke Agen dan dari Agen ke Kelurahan (demand point),

6) Data penjualan yang digunakan adalah data penjualan di BPS Kota Bandung tahun 2013,

7) Metode peramalan yang digunakan pada penelitian ini adalah Metode Konstan, Regresi Linear, Single Exponencial Smoothing dengan $\alpha$ sebesar 0,2, 0,5 , dan 0,9, Double Exponencial Smoothing dengan $\alpha$ sebesar 0,2 , 0,5, dan 0,9, dan metode Moving Average Periode 3 bulan dan 5 bulan. Standar error yang digunakan adalah SEE.
Asumsi yang dilakukan dipenelitian ini di antaranya adalah :

1) Data permintaan/ demand berdasarkan banyaknya Kepala Keluarga di Kota Bandung, dengan asumsi kebutuhan LPG $3 \mathrm{~kg}$ di tiap kelurahan sebesar $70 \%$.

2) Kapasitas Truk Agen dibagi menjadi dua yaitu truk besar adalah 560 tabung dan truk kecil sebesar 360 tabung, maka kapastas Agen diasumsikan minimal sebesar 920 per bulan,

3) 1 liter premium/ solar untuk $12 \mathrm{~km}$ sehingga ongkos transportasi dari Agen ke Demand point untuk sistem tertutup sebesar Rp. 616,67,

4) Proyeksi pertumbuhan penduduk diasumsikan sama dengan kebutuhan akan gas bumi berdasarkan data dari ESDM yaitu untuk tahun 2015-2020 akan meningkat sebesar 6\% per tahun, tahun 2020-2025 meningkat sebesar 7\% dan pada tahun 2025-2030 meningkat sebesar $5 \%$ pertahun,

5) Kapasitas SPPBE tak terbatas (Pertamina berhak menaikkan kuota (kapasitas) SPPBE),

6) Kapasitas SPPBE ditentukan sebesar 12.000 MT pertahun, (Muchlis, Stefanus Eko Wiratno, 2009))

7) Wilayah alternatif berdasarkan wilayah Kecamatan.

\section{Bahan Dan Metode}

Rancangan penelitian yang penulis lakukan dapat dilihat jelas pada gambar diagram alir penelitian secara umum di bawah ini. Selanjutnya peneliti akan menjabarkan setiap langkah yang dilakukan pada penelitian ini seperti yangakan dibahas pada subbab berikutnya.

\section{Perhitungan Jarak}

Perhitungan ini dilakukan untuk menghitung jarak antara SPPBE ke Agen dan Agen ke Demand Point (kecamatan). Jarak antara SPPBE dengan Agen serta Agen dengan demand point (kecamatan) akan dihitung dengan menggunakan metode Euclidean. Ada beberapa data jarak yang digunakan adalah koordinat lokasi berupa longitude dan latitude, , maka akan dihitung jarak antar lokasi dengan persamaan yang ditentukan oleh Simchi, 1997. Persamaan tersebut digunakan untk menghitung jarak antar dua titik di bumi. Berikut ini merupakan rumus perhitungannya: (Anggaini, 2010)

$$
D_{12}=69 \sqrt{\left(\operatorname{long}_{1}-\operatorname{long}_{2}\right)^{2}+\left(\text { lat }_{1}-\text { lat }_{2}\right)^{2}}
$$

\section{Perhitungan Kebutuhan LPG per Kelurahan}

Untuk perancangan distribusi untuk sistem tertutup ada beberpa hal yang harus dilakukan yaitu menghitung permintaan. Perhitungan demand point merupakan banyaknya permintaan akan LPG $3 \mathrm{~kg}$ berdasarkan banyaknya penduduk tiap Kelurahan. Data-data yang mempengaruhi permintaan akan LPG $3 \mathrm{~kg}$ di antaranya adalah sebagai berikut ini: Jumlah 
Kepala Keluarga (KK) per kelurahan dan Jumlah warung makan dan rumah makan per kelurahan.

Maka rumus untuk melakukan perhitungan kebutuhan akan LPG $3 \mathrm{~kg}$ per bulan adalah sebagai berikut :

$$
d_{k}=\text { konsumen }=\frac{31 \text { hari }}{\text { lama pemakaian }}
$$

Maka banyaknya kebutuhan (demand) akan LPG 3 kg per bulan per kelurahan adalah :

$d_{\text {tot }}=\left(d_{k} *\right.$ jumlah $\left.R T\right)$

$$
+\left(d_{k} * \text { jumlah warung makan }\right)
$$

\section{Optimasi Distribusi LPG}

\section{Parameter Penelitian}

Penelitian ini dilakukan di wilayah Bandung kota dengan skema penyediaan pendistribusian LPG 3 $\mathrm{kg}$ yang terjadi saat ini (eksisting-sistem terbuka) adalah pasokan bulk LPG dipasok oleh Depot area Pertamina, lalu Agen datang membeli LPG dalam kemasan tabung $3 \mathrm{~kg}$ dengan cara melakukan pengisian ulang tabung LPG $3 \mathrm{~kg}$ ke SPPBE. Agen melakukan pemasaran LPG ke wilayah mana saja tetetapi masih dalam wilayah pemasaran (Kota Bandung bukan Kebupaten Bandung). Gambar 3 akan menggambarkan skema pendistribusian LPG $3 \mathrm{~kg}$ eksisting .

Sedangkan skema pendistribusian LPG $3 \mathrm{~kg}$ berdasarkan distribusi sistem tertutup (closed system) di mana wilayah pemasaran setiap SPPBE berbeda dan tiap Agen pun memiliki wilayah pemasaran yang berbeda.

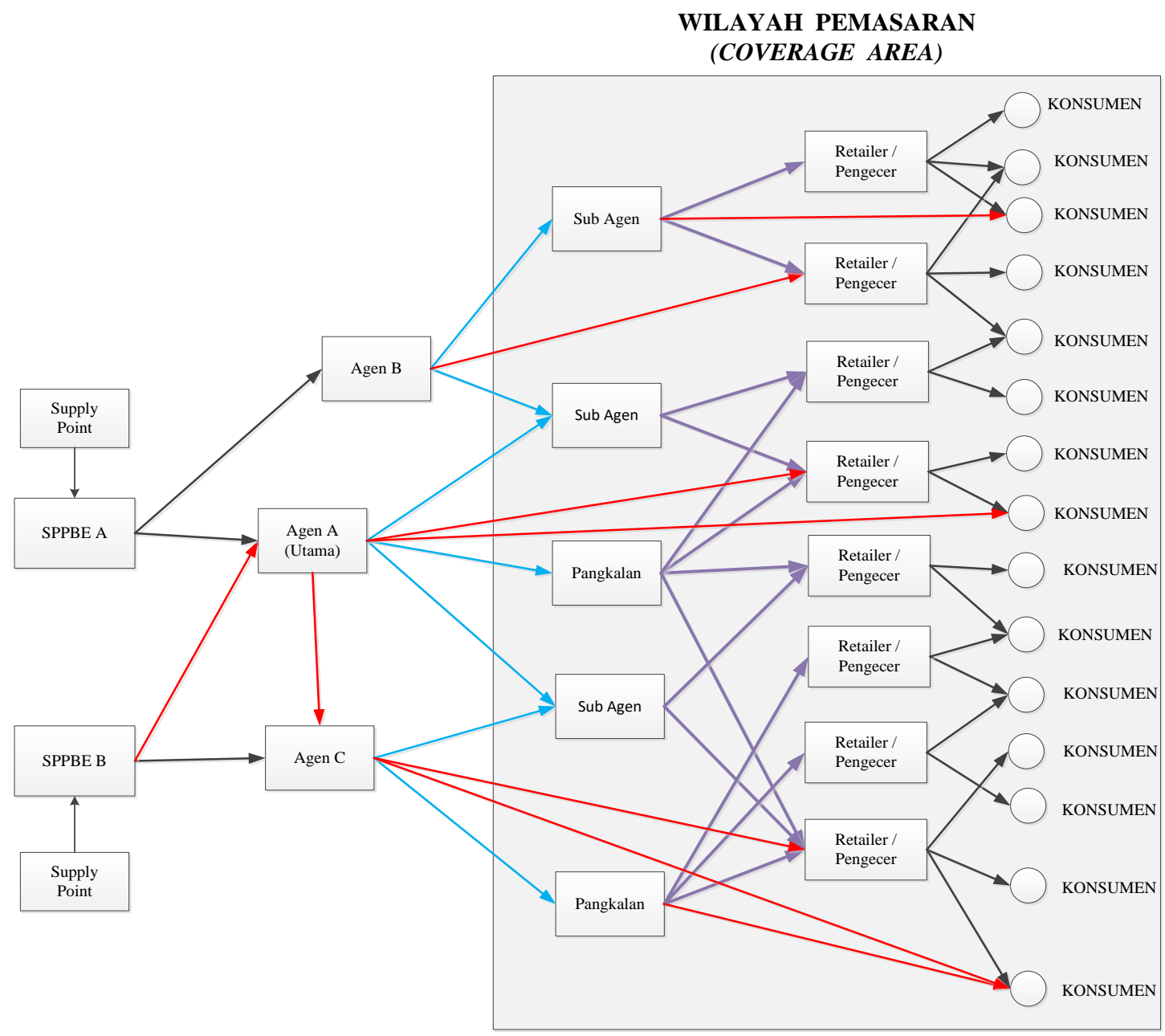

Gambar 2 Skema Distribusi Sistem Terbuka 


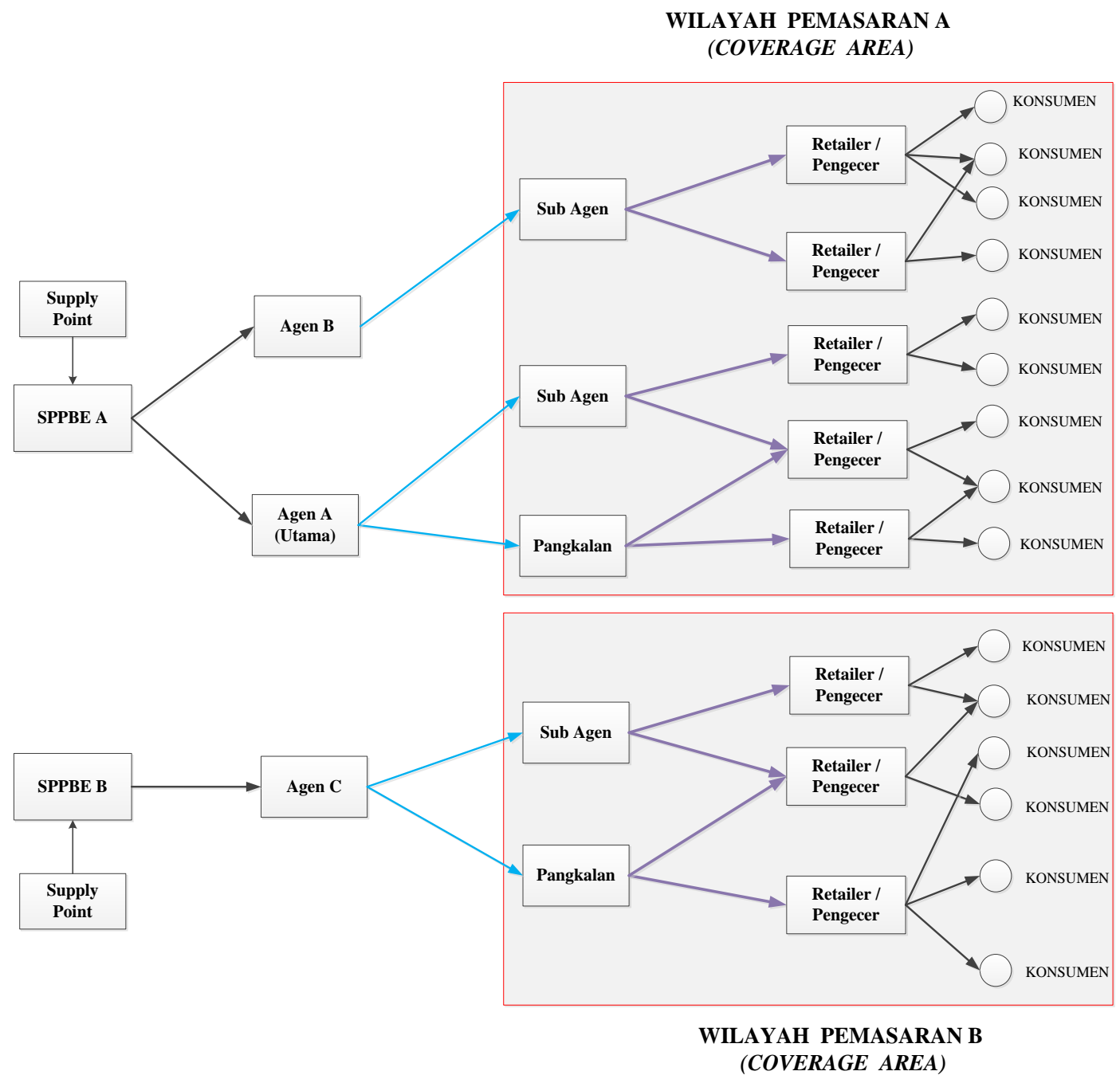

Gambar 3 Skema Distribusi Sistem Tertutup

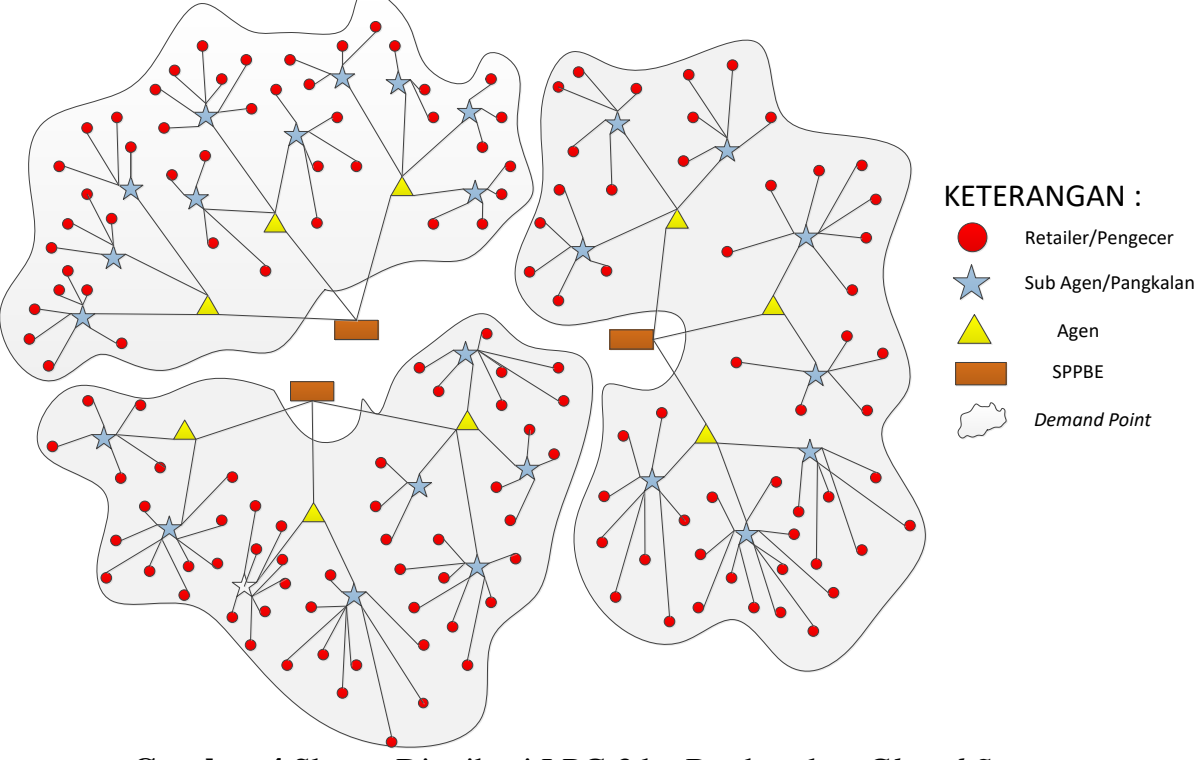

Gambar 4 Skema Distribusi LPG 3 kg Berdasarkan Closed System

Model distribusi tertutup yang menjadi kajian pada penelitian ini dapat digambarkan lebih jelas pada gambar 4 skema distribusi closed system berikut ini.
Tujuan Pemerintah melakukan distribusi sistem tertutup adalah untuk mentertibkan pengisian dan pendistribusian LPG $3 \mathrm{~kg}$. Sedangkan tujuan dari setiap distribusi adalah meminimasi ongkos distribusi. 
Jika dilihat dari permasalahan yang terjadi pada distribusi LPG $3 \mathrm{~kg}$ berdasarkan sistem tertutup, maka penentuan wilayah pemasaran tiap SPPBE yang menjadi permasalahannya. Metode transportasi merupakan metode yang bertujuan untuk menetapkan suplai yang cukup untuk beberapa lokasi tujuan dari beberapa dengan minimum biaya untuk pabrik dan kapasitas DC.

Dilihat dari skema distribusi sistem tertutup LPG $3 \mathrm{~kg}$ maka metode transportasi dipandang dapat menyelesaikan permasalahan dari distribusi sistem tertutup LPG $3 \mathrm{~kg}$. Karena dengan metode transportasi, peneliti dapat memperoleh hasil akhir berupa wilayah pemasaran dan jumlah tabung yang didistribusikan oleh Agen berdasarkan minimasi ongkos dan serta jarak. Pada gambar 5 dapat dilihat variabel yang mempengaruhi dalam permasalahan distribusi sistem tertutup.

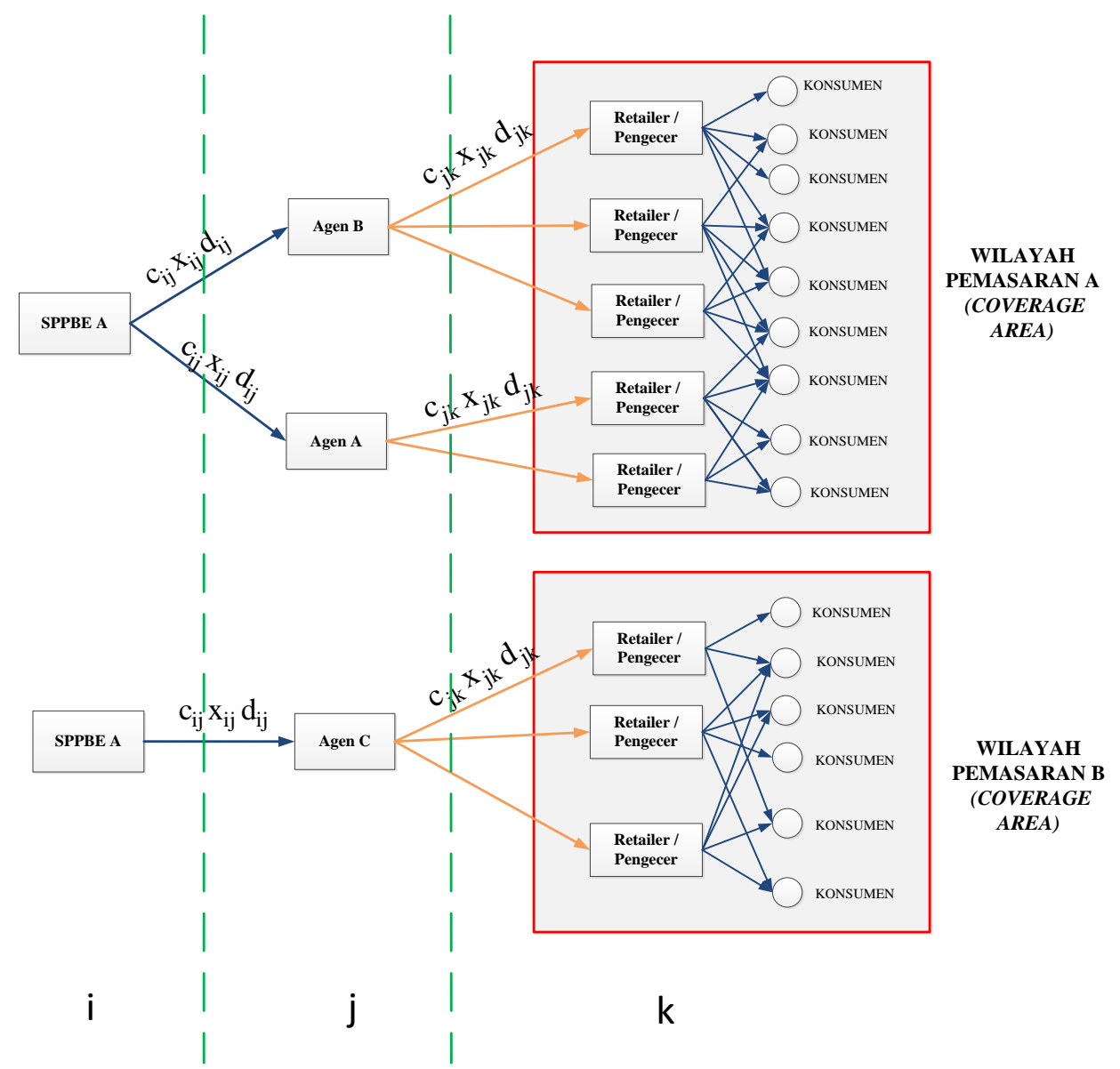

Gambar 5. Variabel-variabel yang Mempengaruhi Distribusi LPG 3 Kg

Pada permasalahan distribusi system tertutup LPG $3 \mathrm{~kg}$ terdapat beberapa variabel yang mempengaruhinya di antaranya adalah :

1. $\mathrm{C}_{\mathrm{ij}}$ : biaya transportasi dari SPPBE ke Agen

2. $\mathrm{X}_{\mathrm{ij}}$ : Jumlah unit yang dikirimkan

3. $\mathrm{d}_{\mathrm{ij}}$ : Jarak dari SPPBE ke Agen

di mana ; $\mathrm{i}=\mathrm{SPPBE}, \mathrm{j}=$ Agen, dan, $\mathrm{k}=$ Retailer (demand point berdasarkan kelurahan)

Maka rumusan Metode transportasi dengan linear programming dapat ditulis sebagai berikut :

\section{Fungsi Objektif :}

\section{Sistem Terbuka}

Minimasi Ongkos :

$$
\sum_{i=1}^{n} \sum_{j=1}^{m} c_{i j} x_{i j} d_{i j}+\sum_{j=1}^{m} \sum_{k=1}^{p} c_{j k} y_{j k} d_{j k}
$$

Sistem Tertutup

Minimasi Ongkos SPPBE ke Demand point:

$$
\sum_{i=1}^{n} \sum_{j=1}^{m} c_{i j} x_{i j} d_{i j}+\sum_{j=1}^{m} \sum_{k=1}^{p} c_{j k} x_{j k} d_{j k}
$$

a) Faktor Pembatas (Constraint)

a. Untuk sistem terbuka :

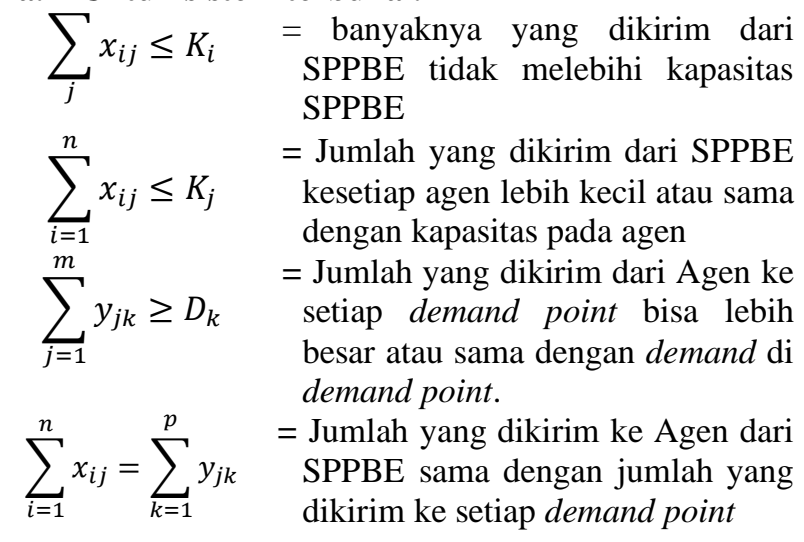




$$
\begin{gathered}
x_{i j}, x_{j k} \geq 0 \\
x_{i j}, x_{j k}=\text { integer }
\end{gathered}
$$

b. Untuk sistem tertutup:

$$
\sum_{i=1}^{n} y_{i j} \leq B
$$

= banyaknya binary penugasan tidak melebihi jumlah Agen, artinya satu SPPBE boleh melayani lebih dari satu Agen tetapi tidak boleh melebihi dari jumlah total Agen

$$
\sum^{m} \quad=\text { total binary penugasan SPPBE- }
$$

Agen sama dengan 1, artinya satu Agen hanya dilayani oleh satu SPPBE

$x_{i j}=K_{j} y_{i j} \quad=$ banyaknya yang dikirim dari SPPBE sama dengan Kapasitas Agen dikalikan dengan binary alokasi untuk SPPBE - Agen

$$
\begin{aligned}
& \sum_{i=1}^{n} x_{i j} \leq K_{i} \\
& \sum_{i=1}^{n} y_{j k} \leq R
\end{aligned}
$$

= banyaknya yang dikirim dari SPPBE tidak melebihi kapasitas SPPBE

= banyaknya binary penugasan tidak melebihi jumlah Kelurahan, artinya satu Agen boleh melayani lebih dari satu Kelurahan tetapi tidak boleh melebihi dari jumlah total Kelurahan

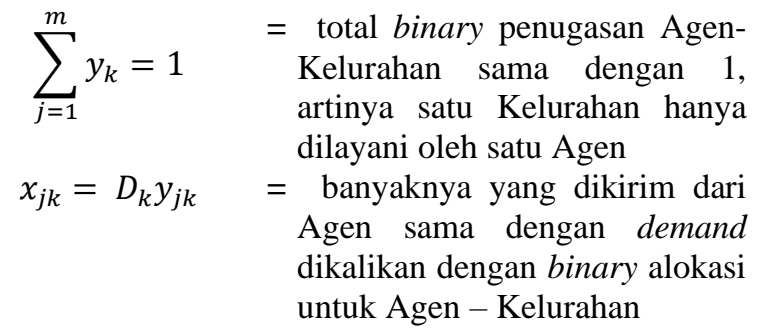

$$
\begin{gathered}
\sum_{i=1}^{n} x_{i j}=\sum_{j=1}^{m} x_{j k} \\
\sum_{\substack{p=1 \\
p}}^{p} x_{j k} \geq 920 \\
\sum_{k=1}^{p} x_{j k}=K_{j}
\end{gathered}
$$

$$
\begin{gathered}
K_{j} \geq 920 \text { kapasitas minimal agen sebesar } \\
920 \text { tabung } \\
x_{i j}, x_{j k} \geq 0 \\
y_{i j}, y_{j}, y_{j k}, y_{k}=\text { Binary }(0,1) \\
x_{i j}, x_{j k}=\text { integer }
\end{gathered}
$$

Keterangan Notasi :

$$
\begin{aligned}
& i=\text { Index untuk } \\
& \text { SPPBE }(1,2, \ldots n) \\
& j \quad=\text { Indeks untuk } \\
& \text { Agen }(1,2, . . \mathrm{m}) \\
& k=\text { Indeks untuk } \\
& \text { demand point } \\
& (1,2, \ldots \mathrm{p}) \\
& D_{k}=\text { permintaan } \\
& \text { bulanan dari } \\
& \text { demand point } \\
& d_{j k}=\text { Jarak antara } \\
& \text { Agen ke Demand } \\
& \text { point } \\
& d_{i k}=\text { jarak antara } \\
& \text { SPBBE ke } \\
& \text { demand point } \\
& d_{i j}=\text { jarak antara } \\
& \text { SPPBE ke Agen } \\
& K_{i}=\text { Kapasitas } \\
& \text { bulanan SPPBE } \\
& c_{i k}=\text { biaya } \\
& \text { transportasi } \\
& \text { SPPBE - } \\
& \text { Demand point } \\
& y_{i j}=1 \text { bila SPPBE } \\
& \text { dipilih dan } 0 \text { jika } \\
& \text { tidak } \\
& y_{j}=1 \text { bila Agen } \\
& \text { dipilih dan } 0 \text { jika } \\
& \text { tidak } \\
& x_{i j}=\text { volume yang } \\
& \text { dikirim dari } \\
& \text { SPPBE ke Agen } \\
& x_{j k}=\text { volume yang } \\
& \text { dikirim Agen ke } \\
& \text { Demand point } \\
& x_{i k}=\text { volume yang } \\
& \text { dikirim SPBBE } \\
& \text { ke demand point } \\
& K_{j}=\text { Kapasitas } \\
& \text { bulanan Agen } \\
& c_{i j}=\text { ongkos } \\
& \text { transportasi } \\
& \text { SPPBE-Agen } \\
& c_{j k} \underset{\text { transportasi }}{=} \text { biaya } \\
& \text { Agen- Demand } \\
& \text { point } \\
& B \text { = banyaknya Agen } \\
& =31 \\
& R=\text { Banyaknya } \\
& \text { Kelurahan }=151
\end{aligned}
$$

Untuk mengidentifikasi lokasi alternatif pendirian SPPBE baru, pendekatan kualitatif harus diterapkan pada tahap ini karena setelah dilakukan perancangan distribusi LPG $3 \mathrm{~kg}$ maka perlu diketahui lokasi (coverage area) yang memiliki hubungan terbesar terhadap kriteria pemilihan lokasi. Berikut ini kriteria dan faktor keputusan yang menjadi bahan kajian didalam kuesioner.

Tabel 1 Kriteria dan Faktor Keputusan Penentuan Lokasi SPPBE

\begin{tabular}{cll}
\hline No. & \multicolumn{1}{c}{ Kriteria } & \multicolumn{1}{c}{ Faktor Keputusan } \\
\hline 1 & Keadaan populasi & Jumlah populasi, tingkat pendapatan \\
\hline 2 & Kondisi transportasi & $\begin{array}{l}\text { Kestrategisan, jumlah transportasi umum, jumlah pejalan kaki, arus lalu } \\
\text { lintas, tingkat kemacetan lalu lintas, ketersediaan transportasi umum, } \\
\text { jalan raya yang besar }\end{array}$ \\
\hline 3 & Kondisi Pasar & $\begin{array}{l}\text { Jumlah kepala keluarga, jumlah Warung makan, jumlah PKL, jumlah } \\
\text { Pasar Tradisional, kedekatan dengan pusat perbelanjaan }\end{array}$ \\
\hline 4 & Kondisi lokasi & $\begin{array}{l}\text { Luas lokasi, mudah dilihat. kedekatan dengan depot Pertamina, } \\
\text { kedekatan dengan pemukiman warga, kedekatan dengan listrik tekanan } \\
\text { tinggi }\end{array}$ \\
\hline 5 & Biaya yang terkait & Biaya tanah, pajak, biaya produksi, status kepemilikan lahan, profit \\
\hline
\end{tabular}




\section{Hasil Dan Pembahasan}

Pada tahap pengolahan hasil penelitian, peneliti melakukan dua tahapan penyelesian permasalahan yaitu :

1) Perhitungan Ongkos Distribusi

Perhitungan ongkos distribusi dilakukan untuk mempermudah perhitungan dengan menggunakan excel solver. Di Kota Bandung terdapat enam buah SPPBE tetapi hanya tiga SPPBE yang ditugaskan untuk pengisian tabung LPG $3 \mathrm{~kg}$ di antaranya adalah :

1. SPPBE Wira Bangun Sarana (SPPBE 1)

2. SPPBE Patra Trading Ujung Berung (SPPBE 2),

3. SPPBE Purnatarum Murni Rahayu Putra (SPPBE4)

Tabel 2 Contoh Hasil Perhitungan Jarak SPPBE - KELURAHAN

\begin{tabular}{|c|c|c|c|c|c|}
\hline \multicolumn{2}{|c|}{ KELURAHAN SPPBE } & \multirow{2}{*}{$\begin{array}{c}\text { Koordinat } \\
6,97 \\
107,64\end{array}$} & \multirow{2}{*}{$\frac{1}{10,176}$} & \multirow{2}{*}{$\frac{2}{9,475}$} & \multirow{2}{*}{$\frac{3}{9,424}$} \\
\hline SPPBE Wira Bangun Sarana & SPPBE 1 & & & & \\
\hline SPPBE Patra Trading Ujung Berung & SPPBE 2 & $\begin{array}{c}6,94 \\
107,64 \\
107,69\end{array}$ & 9,885 & 9,312 & 9,655 \\
\hline $\begin{array}{l}\text { SPPBE Purnatarum Murni Rahayu } \\
\text { Putra }\end{array}$ & SPPBE 4 & $\begin{array}{c}6,94 \\
107,64 \\
107,68 \\
\end{array}$ & 9,969 & 9,396 & 9,739 \\
\hline
\end{tabular}

Sumber: Hasil Pengolahan Data

Tabel 3 Contoh Hasil Perhitungan Ongkos Distribusi dari SPPBE ke Kelurahan

\begin{tabular}{ccccccc}
\hline Kel. SPPBE & Trans. Fee & 1 & 2 & 3 & 4 & 5 \\
\hline SPPBE 1 & Rp 390,10 & $2.326,15$ & $2.153,36$ & $2.404,81$ & $2.360,25$ & $1.547,66$ \\
SPPBE 2 & Rp 390,10 & $1.949,71$ & $1.790,55$ & $2.071,10$ & $2.051,34$ & $1.169,85$ \\
SPPBE 4 & Rp 390,10 & $1.326,33$ & $1.134,59$ & $1.395,74$ & $1.382,71$ & 572,04 \\
\hline
\end{tabular}

Sumber: Hasil Pengolahan Data

\section{Optimasi Ongkos Distribusi LPG 3 kg}

Optimasi ongkos distribusi yang akan dibahas pada penelitian ini adalah ongkos distribusi LPG dengan sistem Terbuka dan Sistem Tertutup.

\section{a) Sistem Terbuka}

Tabel 4. Hasil Perhitungan Optimasi SPPBE - Agen (dalam satuan tabung),

\begin{tabular}{|c|c|c|c|c|c|c|c|c|}
\hline Agen SPPBE & $\begin{array}{c}\text { Agen } \\
1\end{array}$ & $\begin{array}{c}\text { Agen } \\
2\end{array}$ & Agen 3 & $\ldots .$. & Agen 30 & Agen 31 & TOTAL & KAP. SPPBE \\
\hline SPPBE 1 & 0 & 27881 & 0 & $\ldots .$. & 0 & 155574 & 866927 & 930.000 \\
\hline SPPBE 2 & 20929 & 0 & 76658 & $\ldots .$. & 98749 & 0 & 1054000 & 1.054 .000 \\
\hline SPPBE 4 & 0 & 0 & 0 & $\ldots .$. & 0 & 0 & 802900 & 802.900 \\
\hline TOTAL & 20.929 & 27.881 & 76.658 & $\ldots .$. & 98.749 & 155.574 & & \\
\hline KAP. Agen & 20.929 & 27.881 & 76.658 & $\ldots \ldots$ & 98.749 & 155.574 & & - \\
\hline
\end{tabular}

Sumber: Hasil Pengolahan Data

Tabel 5. Hasil Perhitungan Optimasi Agen - Kelurahan (dalam satuan tabung)

\begin{tabular}{cccccccc}
\hline KELURAHAN AGEN & 1 & 2 & 3 & $\ldots \ldots$ & 151 & TOTAL & $\begin{array}{c}\text { KAP. } \\
\text { Agen }\end{array}$ \\
\hline Agen 1 & 0 & 0 & 0 & $\ldots \ldots$ & 0 & 20929 & 920 \\
Agen 2 & 0 & 0 & 0 & $\ldots \ldots$ & 0 & 27881 & 920 \\
Agen 3 & 0 & 0 & 0 & $\ldots \ldots$ & 0 & 76658 & 920 \\
$:$ & $:$ & $:$ & $:$ & $\ldots \ldots$ & $:$ & $:$ & $:$ \\
$:$ & $:$ & $:$ & $:$ & $\ldots \ldots$ & 155574 & 920 \\
Agen 31 & 0 & 0 & 10741 & $\ldots \ldots$ & 0 & & \\
TOTAL & 21459 & 31483 & 10741 & $\ldots \ldots$ & 12486 & & \\
DEMAND & 21459 & 31483 & 10741 & $\ldots \ldots$ & 12486 & & \\
\hline
\end{tabular}

Berdasarkan hasil perhitungan dengan menggunakan Excel Analytic Solver Platform diperoleh Ongkos
Transportasi LPG $3 \mathrm{~kg}$ berdasarkan Sistem Terbuka adalah sebesar Rp 8.319.765.767,07.

b) Sistem Tertutup 
Tabel 6. Penugasan SPPBE ke Agen

\begin{tabular}{lcccccccc}
\hline AGEN SPPBE & Agen 1 & Agen 2 & Agen 3 & $\ldots$. & Agen 30 & Agen 31 & TOTAL & Total SPPBE \\
\hline SPPBE 1 & 0 & 0 & 0 & $\ldots$. & 0 & 1 & 12 & 31 \\
SPPBE 2 & 1 & 1 & 0 & $\ldots$. & 1 & 0 & 12 & 31 \\
SPPBE 4 & 0 & 0 & 0 & $\ldots$. & 0 & 0 & 7 & 31 \\
Total Agen & 1 & 1 & 1 & $\ldots$. & 1 & 1 & & \\
TOTAL & 1 & 1 & 1 & $\ldots$. & 1 & 1 & & \\
\hline
\end{tabular}

Sumber: Hasil Pengolahan Data

Tabel 7. Kapasitas Tiap Agen (satuan tabung)

\begin{tabular}{ccccccc}
\hline AGEN SPPBE & Agen 1 & Agen 2 & Agen 3 & $\ldots$ & Agen 30 & Agen 31 \\
\hline SPPBE 1 & 21.781 & 15.305 & 62.189 & $\ldots$ & 132.593 & 107.741 \\
SPPBE 2 & 21.781 & 15.305 & 62.189 & $\ldots$ & 132.593 & 107.741 \\
SPPBE 3 & 21.781 & 15.305 & 62.189 & $\ldots$ & 132.593 & 107.741 \\
SPPBE 4 & 21.781 & 15.305 & 62.189 & $\ldots$ & 132.593 & 107.741 \\
SPPBE 5 & 21.781 & 15.305 & 62.189 & $\ldots$ & 132.593 & 107.741 \\
SPPBE 6 & 21.781 & 15.305 & 62.189 & $\ldots$ & 132.593 & 107.741 \\
\hline
\end{tabular}

Sumber: Hasil Pengolahan Data

Tabel 8. Hasil Perhitungan Optimasi SPPBE - Agen (satuan tabung)

\begin{tabular}{|c|c|c|c|c|c|c|c|}
\hline AGEN SPPBE & Agen 1 & Agen 2 & Agen 3 & $\ldots .$. & Agen 31 & TOTAL & KAP. SPPBE \\
\hline SPPBE 1 & 0 & 0 & 0 & $\ldots .$. & 107741 & 867473 & 930.000 \\
\hline SPPBE 2 & 21781 & 15305 & 0 & $\ldots$. & 0 & 1.053 .607 & 1.054 .000 \\
\hline SPPBE 4 & 0 & 0 & 0 & $\ldots .$. & 0 & 802.747 & 802.900 \\
\hline TOTAL & 21781 & 15305 & 62189 & $\ldots .$. & 107741 & & \\
\hline KAP. Agen & 21781 & 15305 & 62189 & $\ldots$. & 107741 & & \\
\hline
\end{tabular}

Sumber: Hasil Pengolahan Data

Tabel 9. Penugasan Agen-Kelurahan

\begin{tabular}{lccccccc}
\hline \multicolumn{1}{c}{ KEL. AGEN } & 1 & 2 & 3 & $\ldots$. & 151 & TOTAL & KAP. Agen \\
\hline Agen 1 & 0 & 0 & 0 & $\ldots$. & 0 & 2 & 151 \\
Agen 2 & 0 & 0 & 0 & $\ldots$. & 0 & 2 & 151 \\
Agen 3 & 0 & 0 & 0 & $\ldots$. & 0 & 4 & 151 \\
Agen 4 & 1 & 1 & 1 & $\ldots$. & 0 & 13 & 151 \\
$\ldots .$. & $\ldots$. & $\ldots \ldots$ & $\ldots \ldots$ & $\ldots$. & $\ldots \ldots$ & $\ldots \ldots$ & $\ldots .$. \\
Agen 30 & 0 & 0 & 0 & $\ldots$. & 0 & 6 & 151 \\
Agen 31 & 0 & 0 & 0 & $\ldots$. & 0 & 6 & 151 \\
TOTAL Kel. & 1 & 1 & 1 & $\ldots$. & 1 & & \\
TOTAL & 1 & 1 & 1 & $\ldots$. & 1 & & \\
\hline
\end{tabular}

Sumber: Hasil Pengolahan Data

Tabel 10. Hasil Perhitungan Optimasi SPPBE - Agen (satuan tabung)

\begin{tabular}{lccccccc}
\hline \multicolumn{1}{c}{ KEL. AGEN } & 1 & 2 & 3 & $\ldots$. & 151 & TOTAL & KAP. Agen \\
\hline Agen 1 & 0 & 0 & 0 & $\ldots$. & 0 & 21781 & 920 \\
Agen 2 & 0 & 0 & 0 & $\ldots$. & 0 & 15305 & 920 \\
Agen 3 & 0 & 0 & 0 & $\ldots$. & 0 & 62189 & 920 \\
Agen 4 & 21459 & 31483 & 10741 & $\ldots$. & 0 & 298665 & 920 \\
$\ldots .$. & $\ldots \ldots$ & $\ldots \ldots$ & $\ldots \ldots$ & $\ldots$. & $\ldots \ldots$ & $\ldots \ldots$ & $\ldots$. \\
Agen 30 & 0 & 0 & 0 & $\ldots$. & 0 & 132593 & 920 \\
Agen 31 & 0 & 0 & 0 & $\ldots$. & 0 & 107741 & 920 \\
TOTAL & 21459 & 31483 & 10741 & $\ldots$. & 12486 & & \\
DEMAND & 21459 & 31483 & 10741 & $\ldots$. & 12486 & & \\
\hline
\end{tabular}

Sumber: Hasil Pengolahan Data

Berdasarkan hasil perhitungan dengan menggunakan Excel Analytic Solver Platform diperoleh Ongkos Transportas LPG 3kg berdasarkan Sistem Tertutup adalah sebesar Rp 8.724.410.280,30.

Besarnya ongkos transportasi dengan sistem tertutup lebih besar dibandingkan dengan ongkos distribusi terbuka yaitu sebesar Rp. 404.644.513,23. Hal ini dikarenakan pada sistem tertutup satu Agen hanya boleh menerima LPG dari satu SPPBE, sedangkan pada sistem terbuka Agen boleh mengambil LPG dari lebih dari satu SPPBE. Begitu 
pula dengan penjualan yang dilakukan oleh satu kelurahan hanya boleh dilayani oleh satu Agen.

\section{2) Coverage Area}

Coverage area untuk distribusi sistem tertutup dibagi menjadi dua yaitu coverage area SPPBE ke Agen dan Agen ke Kelurahan (konsumen). Untuk coverage area SPPBE ke Agen, adalah sebagai berikut :

- SPPBE 1 memiliki wilayah pemasaran untuk Agen 4, Agen 6, Agen 7,Agen 10, Agen 11, Agen 16, Agen 20, Agen 21, Agen 23, Agen 24, Agen 25, dan Agen 31 dengan kapasitas SPPBE yang terpakai sebesar 867.473 tabung per bulan dari kapasitas total sebesar 930.000 tabung per bulan.

- SPPBE 2 memiliki wilayah pemasaran untuk Agen 1, Agen 2, Agen 5,Agen 8, Agen 11, Agen 12, Agen 15, Agen 17, Agen 18, Agen 19, Agen 26 dan Agen 30 dengan kapasitas SPPBE 2 yang terpakai yaitu sebesar 1.053.607 dari total kapasitas 1.054.000 tabung per bulan.

- SPPBE 4 memiliki wilayah pemasaran untuk Agen 3, Agen 9, Agen 14, Agen 22, Agen 27, Agen 28, dan Agen 29 dengan kapasitas SPPBE 4 yang terpakai yaitu sebesar sebesar 802.747 dari total kapasitas 802.900 tabung per bulan.

\section{Evaluasi Kebutuhan SPPBE Hingga Tahun 2030 Mendatang}

Evaluasi kebutuhan dilakukan untuk mengetahui perkiraan permintaan dari tahun 20152030. Pada bagian evaluasi ini pengerjaan dibagi menjadi tiga bagian, yaitu :

1. Perkiraan permintaan LPG $3 \mathrm{~kg}$ berdasarkan prediksi ESDM,

2. Perkiraan permintaan LPG $3 \mathrm{~kg}$ berdasarkan metode Forecasting,

3. Perkiraan Lokasi untuk pendiriaan SPPBE baru.

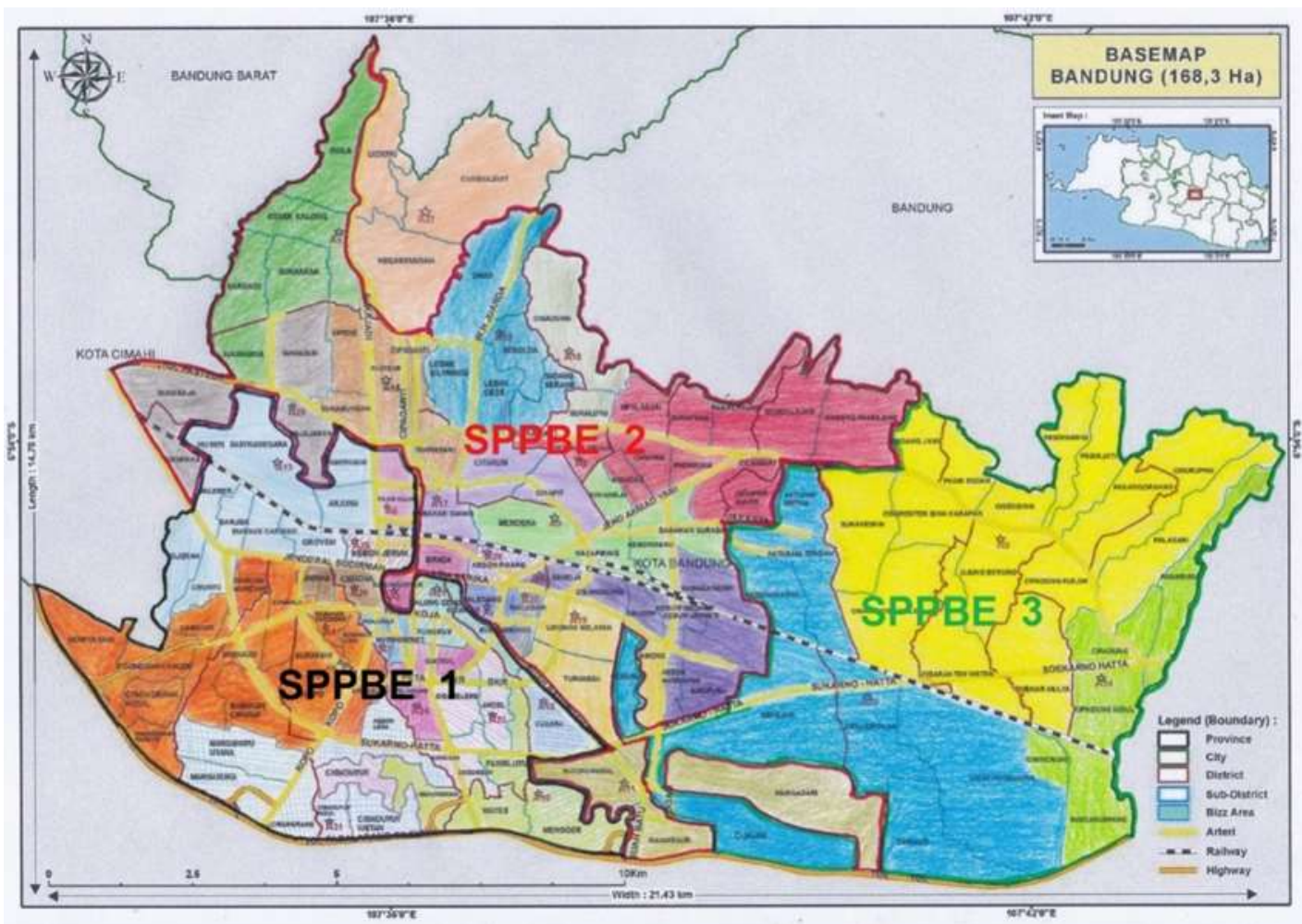

Gambar 5 Peta Coverage Area SPPBE untuk Distribusi Sistem Tertutup

\section{Perkiraan Permintaan LPG $3 \mathrm{~kg}$ Berdasarkan Prediksi ESDM}

Perhitungan dilakukan berdasarkan prediksi peningkatan kebutuhan migas oleh ESDM. Di mana peningkatan permintaan yang telah diprediksi oleh ESDM, adalah sebagai berikut :

1) Pada tahun 2015-2020 akan meningkat sebesar 6 $\%$ per tahun,

2) Pada tahun $2020-2025$ kebutuhan akan gas bumi meningkat sebesar $7 \%$, dan

3) Pada tahun 2025-2030 meningkat sebesar 5\% pertahun.
4)

\section{Perkiraan Permintaan LPG 3kg Berdasarkan Metode Forecasting}

Untuk perkiraan permintaan berdasarkan metode forecasting dilakukan dengan menggunakan data permintaan penjualan LPG $3 \mathrm{~kg}$ pada tahun 2013 yang diperoleh dari BPS Kota Bandung. Berdasarkan hasil perhitungan peramalan maka Standar Error (SEE) yang terkecil adalah berdasarkan metode Regresi Linear dengan nilai SEE sebesar 115129. 
Tabel 11 Kesimpulan Hasil Akhir Perhitungan Kecukupan dan Kekurangan SPPBE Berdasarkan Hasil Perkiraan ESDM (dalam satuan tabung)

\begin{tabular}{|c|c|c|c|c|c|c|c|c|c|c|}
\hline \multirow[b]{2}{*}{ Th. } & \multirow[b]{2}{*}{$\begin{array}{l}\text { Total / } \\
\text { Bulan }\end{array}$} & \multirow[b]{2}{*}{$\begin{array}{l}\text { Total / } \\
\text { Tahun }\end{array}$} & \multirow[b]{2}{*}{$\begin{array}{c}\text { Kap. } \\
\text { SPPBE }\end{array}$} & \multirow[b]{2}{*}{$\begin{array}{l}\text { Selisih } \\
(3)-(4)\end{array}$} & \multicolumn{3}{|c|}{ Alternatif 1} & \multicolumn{3}{|c|}{ Alternatif 2} \\
\hline & & & & & $\begin{array}{c}(-) \\
\text { SPPB } \\
\text { E }\end{array}$ & $\begin{array}{c}(+) \\
\text { Kapasita } \\
\text { S }\end{array}$ & $\begin{array}{l}\text { Selisih } \\
(3)-(7)\end{array}$ & $\begin{array}{c}\text { Penambahan } \\
\text { Kuota Tiap } \\
\text { SPPBE/Th }\end{array}$ & $\begin{array}{l}\text { Penambahan } \\
\text { Kuota Tap } \\
\text { SPPBE/bln }\end{array}$ & $\begin{array}{c}\text { Penambahan } \\
\text { Kuota } \\
\text { SPPBE/hari }\end{array}$ \\
\hline 2014 & $\begin{array}{c}2.723 .82 \\
7\end{array}$ & $\begin{array}{c}32.685 .92 \\
4\end{array}$ & $\begin{array}{c}36.000 .0 \\
00\end{array}$ & 3.314 .076 & & & & & & \\
\hline 2015 & $\begin{array}{c}2.887 .32 \\
3\end{array}$ & $\begin{array}{c}34.647 .87 \\
6\end{array}$ & $\begin{array}{c}36.000 .0 \\
00\end{array}$ & 1.352 .124 & & & & & & \\
\hline 2016 & $\begin{array}{c}3.060 .63 \\
4\end{array}$ & $\begin{array}{c}36.727 .60 \\
8\end{array}$ & $\begin{array}{c}36.000 .0 \\
00\end{array}$ & -727.608 & 1 & $\begin{array}{c}48.000 .0 \\
00\end{array}$ & $\begin{array}{c}11.272 .3 \\
92\end{array}$ & 242.536 & 20.211 & 674 \\
\hline : & : & $:$ & $:$ & : & : & : & : & : & : & : \\
\hline 2027 & $\begin{array}{c}5.976 .04 \\
7\end{array}$ & $\begin{array}{c}71.712 .56 \\
4\end{array}$ & $\begin{array}{c}36.000 .0 \\
00\end{array}$ & $\begin{array}{c}- \\
35.712 .56 \\
4\end{array}$ & & $\begin{array}{c}72.000 .0 \\
00\end{array}$ & 287.436 & 11.904 .188 & 992.016 & 33.067 \\
\hline 2028 & $\begin{array}{c}6.274 .92 \\
5\end{array}$ & $\begin{array}{c}75.299 .10 \\
0\end{array}$ & $\begin{array}{c}36.000 .0 \\
00\end{array}$ & $\begin{array}{c}- \\
39.299 .10 \\
0\end{array}$ & 1 & $\begin{array}{c}84.000 .0 \\
00\end{array}$ & $\begin{array}{c}8.700 .90 \\
0\end{array}$ & 13.099 .700 & 1.091 .642 & 36.388 \\
\hline 2029 & $\begin{array}{c}6.588 .73 \\
9\end{array}$ & $\begin{array}{c}79.064 .86 \\
8\end{array}$ & $\begin{array}{c}36.000 .0 \\
00\end{array}$ & $\begin{array}{c}- \\
43.064 .86 \\
8\end{array}$ & & $\begin{array}{c}84.000 .0 \\
00\end{array}$ & $\begin{array}{c}4.935 .13 \\
2\end{array}$ & 14.354 .956 & 1.196 .246 & 39.875 \\
\hline 2030 & $\begin{array}{c}6.918 .25 \\
1\end{array}$ & $\begin{array}{c}83.019 .01 \\
2\end{array}$ & $\begin{array}{c}36.000 .0 \\
00\end{array}$ & $\begin{array}{c}- \\
47.019 .01 \\
2\end{array}$ & & $\begin{array}{c}84.000 .0 \\
00\end{array}$ & 980.988 & 15.673 .004 & 1.306 .084 & 43.536 \\
\hline
\end{tabular}

Hasil akhir dari perkiraan demand berdasarkan metode forecating dari tahun 2015 hingga 2030 dapat disimpulkan sebagai berikut:

1) Jika Pemerintah dan Pertamina masih memberlakukan kebijakan kalau 1 SPPBE kapasitas maksimum 12.000 MT per tahun maka pada tahun 2015 akan terjadi kekurangan sebanyak 1.967.617 tabung per tahun. Maka idealnya adalah dibutuhkan pendirian $1 \mathrm{SPPBE}$ baru, atau

2) Dibutuhkan penambahan kuota tiap SPPBE sebanyak 655.872 per tahun setara dengan 54.656 per bulan atau 1.822 per hari untuk tiap SPPBE. Dan seterusnya.

3) Hingga tahun 2030 ternyata dibutuhkan 4 SPPBE baru yaitu pada tahun 2015, 2019, 2024 dan 2029.

\section{Perkiraan Lokasi Pendirian SPPBE}

Pada subbab berikut ini penelitian dilakukan secara kualitatif yang bertujuang untuk mengtahui hubungan keterkaitan antara tiap kriteria yang menjadi kriteria yang diperlukan dalam menentukan lokasi pendirian fasilitas/ pabrik/ gudang baru. Dari semua hasil perhitungan AHP dengan bantuan expert choise maka penentuan kriteria yang mampengaruhi keputusan dalam memilih lokasi SPPBE baru dapat diambil kesimpulan bahwa:

1) Lokasi SPPBE harus memiliki luas lokasi yang memenuhi persyaratan yang Pertamina berikan,

2) Lokasi SPPBE harus berdekatan dengan Depot LPG Pertamina.

3) Lokasi SPPBE harus memiliki jalan transportasi yang besar,

4) Status kepemilikan lahan SPPBE harus diperhatikan,
5) Biaya produksi berpengaruh pada keuntungan yang diperoleh, sehingga harus memiliki harga tanah yang bisa lebih menguntungkan.

6) Lokasi SPPBE harus berdekatan dengan jumlah Kepala Keluarga terbanyak dan jumlah warung makan terbanyak.

Dari hasil kriteria di atas maka peneliti mencoba untuk memberikan alternatif lokasi SPPBE berdasarkan kedekatan dengan Depot, Jumlah KK dan warung makan terbesar. Peneliti menentukan beberapa alternatif lokasi yang cocok untuk mendirikan SPPBE baru dengan asumsi kedekatan berada pada radius $2 \mathrm{~km}$ adalah:

Tabel 12 Alternatif Lokasi SPPBE

\begin{tabular}{|c|c|c|}
\hline No & Alternatif Lokasi & Alasan \\
\hline 1 & $\begin{array}{l}\text { Kecamatan Buah } \\
\text { Batu }\end{array}$ & $\begin{array}{l}\text { Berada di antara radius } \\
\text { kedekatan dengan Depot } \\
\text { dan warung makan dan } \\
\text { KK }\end{array}$ \\
\hline 2 & $\begin{array}{l}\text { Kecamatan } \\
\text { Bandung kidul }\end{array}$ & $\begin{array}{l}\text { Berada di antara radius } \\
\text { kedekatan dengan Depot } \\
\text { dan Jumlah KK dan } \\
\text { warung makan } \\
\text { terbanyak. }\end{array}$ \\
\hline 3 & $\begin{array}{l}\text { Kecamatan } \\
\text { Gedebage }\end{array}$ & $\begin{array}{l}\text { Berada di radius } \\
\text { kedekatan dengan Depot }\end{array}$ \\
\hline 4 & $\begin{array}{l}\text { Kecamatan } \\
\text { Cinambo }\end{array}$ & $\begin{array}{l}\text { Berada di radius } \\
\text { kedekatan dengan Depot }\end{array}$ \\
\hline 5 & $\begin{array}{l}\text { Kecamatan } \\
\text { Arcamanik }\end{array}$ & $\begin{array}{l}\text { Berada di radius } \\
\text { kedekatan dengan Depot }\end{array}$ \\
\hline
\end{tabular}

Langkah selanjutnya peneliti melakukan survey dengan menggunakan kuesioner ke berbagai pihak yang terlibat dalam bisnis LPG $3 \mathrm{~kg}$. Setelah itu data hasil kuesioner diolah dengan menggunakan 
metode AHP dengan bantuan software expert choise. Hasil perhitungan expert choise diperoleh overall inconsistency sebesar 0,1 dengan hasil akhir untuk wilayah kec Gedebage sebesar 0,4, wilayah Kec. Cinambo sebesar 0,3, Kec. Arcamanik sebesar 0,1,
Kec. Bandung Kidul sebesar 0,08 dan Kec. Buah Batu sebesar 0,06. Dari hasil akhir tersebut dapat disimpulkan bahwa wilayah Kecamatan Gedebage lebih banyak diminati oleh para sumber untuk mendirikan SPPBE baru.

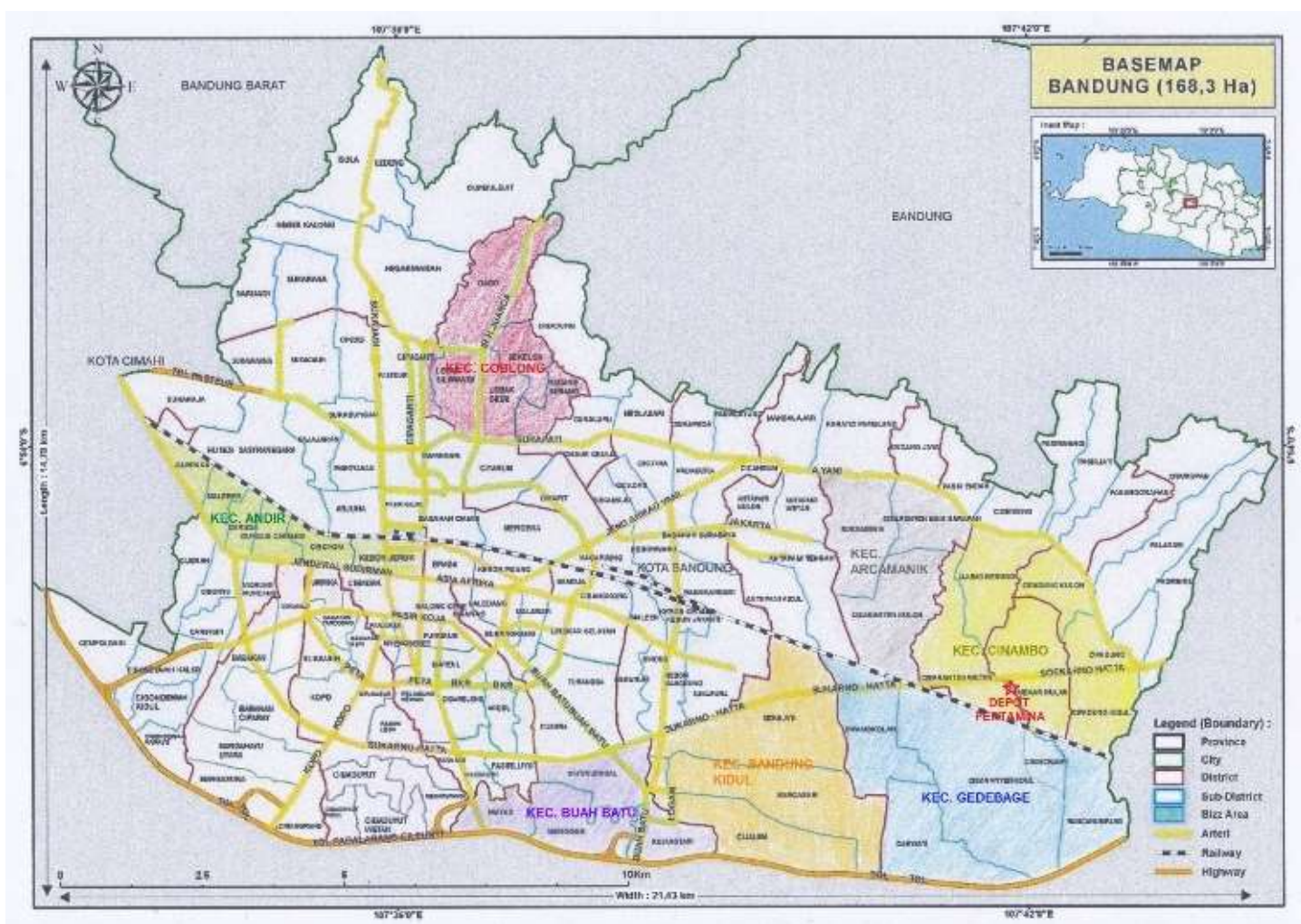

Gambar 6 Lokasi Alternatif pendirian SPPBE Baru

\section{Kesimpulan}

Metode transportasi merupakan salah satu metode yang digunakan untuk menentukan alokasi barang dan letak lokasi fasilitas. Metode transportasi yang terjadi pada sistem distribusi LPG $3 \mathrm{~kg}$ merupakan metode transpotasi tsTP atau metode transportasi dua tahap yaitu dari SPPBE ke Agen dan Agen ke Konsumen. Metode tsTP yang peneliti lakukan adalah berdasarkan linear programming dengan tujuan fungsi objektif adalah ongkos transportasi yang minimum.

Dengan menggunakan software excel Analytic Solver Platform penyelesaian permasalahan linear programing menjadi lebih ringan dan dapat menghasilkan solusi yang mendekati sempurna. Hasil akhir biaya distribusi sistem tertutup lebih besar dibandingkan biaya distribusi sistem terbuka di mana ongkos transportasi sistem terbuka sebesar Rp8.319.765.767,07 sedangkan ongkos trasnportasi sistem tertutup sebesar Rp8.724.410.280,30. dikarenakan lokasi SPPBE lebih terbusat dalam satu titik yang berdekatan dengan depot LPG sedangkan cakupan penjulan sistem distribusi tertutup menyebar.
Untuk coverage area SPPBE ke Agen sistem terbuka, adalah sebagai berikut:

- SPPBE 1 memiliki wilayah pemasaran untuk Agen 2, Agen 4, Agen 7, Agen 10, Agen 11, Agen 13, Agen 16, Agen 20, Agen 23, Agen 24, dan Agen 31 dengan kapasitas SPPBE yang terpakai sebesar 866.927 tabung per bulan dari kapasitas total sebesar 930.000 tabung per bulan.

- SPPBE 2 memiliki wilayah pemasaran untuk Agen 1, Agen 3, Agen 5, Agen 6, Agen 8, Agen 11, Agen 12, Agen 15, Agen 17, Agen 18, Agen 19, Agen 26, Agen 27, Agen 28, Agen 29 dan Agen 30 dengan kapasitas SPPBE 2 semuanya terpakai yaitu sebesar 1.054.000 tabung per bulan.

- 4 memiliki wilayah pemasaran untuk Agen 8, Agen 9, Agen 14 dan Agen 22 dengan kapasitas SPPBE 4 semuanya terpakai yaitu sebesar sebesar 802.900 tabung per bulan.

Coverage area untuk distribusi sistem tertutup dibagi menjadi dua yaitu coverage area SPPBE ke Agen dan Agen ke Kelurahan (konsumen). Untuk coverage area SPPBE ke Agen, adalah sebagai berikut: 
- SPPBE 1 memiliki wilayah pemasaran untuk Agen 4, Agen 6, Agen 7, Agen 10, Agen 11, Agen 16, Agen 20, Agen 21, Agen 23, Agen 24, Agen 25, dan Agen 31 dengan kapasitas SPPBE yang terpakai sebesar 867.473 tabung per bulan dari kapasitas total sebesar 930.000 tabung per bulan.

- SPPBE 2 memiliki wilayah pemasaran untuk Agen 1, Agen 2, Agen 5, Agen 8, Agen 11, Agen 12, Agen 15, Agen 17, Agen 18, Agen 19, Agen 26 dan Agen 30 dengan kapasitas SPPBE 2 yang terpakai yaitu sebesar 1.053.607 dari total kapasitas 1.054.000 tabung per bulan.

- SPPBE 4 memiliki wilayah pemasaran untuk Agen 3, Agen 9, Agen 14, Agen 22, Agen 27, Agen 28, dan Agen 29 dengan kapasitas SPPBE 4 yang terpakai yaitu sebesar sebesar 802.747 dari total kapasitas 802.900 tabung per bulan.

Berdasarkan pada hasil perhitungan expert choise diperoleh overall inconsistency sebesar 0,1 dengan hasil akhir untuk wilayah kec Gedebage sebesar 0,4, wilayah Kec. Cinambo sevesar 0,3, Kec. Arcamanik sebesar 0,1, Kec. Bandung Kidul sebesar 0,08 dan Kec. Buah Batu sebesar 0,06. Dari hasil akhir tersebut dapat disimpulkan bahwa wilayah Kecamatan Gedebage lebih banyak diminati oleh para sumber untuk mendirikan SPPBE baru.

\section{Daftar Pustaka}

Alternatif BBM, achive for SPPBE, Satsiun Bahan Bakar Gas, kutipan pada tanggal 8 November 2012 pada pukul 01.43 WIB. Diakses dari http://Bahanbakarminyak.wordpres.com/ category/ sppbe/, pada tanggal 16 oktober 2014, pukul 00.26 WIB.

Adityawati, A. (2008). Jurnal Tesis : Analisis Jumlah Permintaan Minyak Tanah Berkaitan dengan Kebijakan Pemerintah Dalam Penghematan APBN Melalui Kebijakan Konversi Penggunaan Minyak Tanah Ke LPG. Jakarta: FE-UI.

Berita ESDM, (24 Oktober 2014), (http//www.migas.esdm.go.id)

BPS Kota Bandung, " Kota Bandung Dalam Angka Tahun 2014", http://bandungkota.bps.go .id/ publikasi / kota - bandung -dalam-angka-tahun2014,

Budi Yanto Pargaulan Hutagaol, 2011, Jurnal Tesis : Optimasi Jaringan Sistribusi dari Depot/Terminal LPG ke SPBE/SPPBE Di Pulau Jawa Dengan Menggunakan Algoritma Tabu Search, Fak. Teknik,
Prog. Studi Pascasarjana Teknik Industri, Universitas Indonesia, Jakarta.

Chopra, S. (2007). Supply Chain Management : Strategy, Planning, and Operation. 3rd edition. Singapore: Prentice Hall, 31, 495.

Dikutip dari pernyataan Tua Siagian, Perwakilan Hisna Migas di inilahKoranCom. pada tanggal 26 Februari 2014.

Dystian Anggaini, I Nyoman Pujawan, dan Niniet Indah Arvitrida, 2010, Jurnal Tugas Akhir : "Optimasi Konfigurasi Jaringan Supply Chain Hulu Gas LPG di Indonesia", Jurusan Teknik Industri, Institut Teknologi Sepuluh November (ITS), Surabaya.

Faizatul Widad, (2010),Jurnal Tugas Akhir: RancanganKonfigurasiJaringanLogistik DenganPendekatanJaringanLogistikDen ganPendekatanSistemTertutup (Studi Kasus :Distribusi LPG $3 \mathrm{~kg}$ di Kab./Kota Malang dan Kota Batu).Jurusan Teknik Industri, Institut Teknologi Sepuluh November (ITS), Surabaya.

Heragu, s. S. (2008). Facility Design. CRC Press. http://www.republika.co.id/berita/breakingnews/ekonomi/10/12/15/152324-2014distribusi-lpg-3-kg-sistem-tertutup-seindonesia

http://www.solver.com/solver-tutorial-usingrisk-solver

I Dewa Gd. EkaWiryaG., 2010. Tesis "Penentuan Lokasi Warehousing Baru Dengan Pendekatan Multi Criteria Goal Progamming Untuk Mencapai Efisiensi Rute (Studikasus: $P$ T. $C$ o ca-Cola AmatilIndonesia unit Balinusa), Institut Teknologi Sepuluh November (ITS), Surabaya.

Indrajit R.E, d. R. (2002). Konsep dan Aplikasi Bussines Process Reengineering. Jakarta: Gramedia.

Jabidi. (2012). Jurnal Tesis : Optimasi Distribusi LPG Di Jakarta. Jakarta: Fak. Teknik, Prog. Magister Manajemen Gas, Universitas Indonesia.

Khwanruthai BUNRUAMKAEW (D3), ( March 1st, 2012), How to do AHP analysis in Excel, Division of Spatial Information ScienceGraduate School of Life and Environmental Sciences. University of Tsukuba.

Kompas (2009). Rayonisasi LPG 3 Kilogram, URL:http://cetak. kompas.com/read/xml/2009/08/18/04064 552/rayonisasi,LPG.tiga.kilogram>

Mitsuo Gen, R. C. (2008). Network Models and Optimization : Multiobjective Genetic Algorithm Approach. Springer. 
Muchlis, Stefanus Eko Wiratno, 2010, Jurnal Tugas Akhir: Perancangan Sistem Distribusi $L P G 3 \mathrm{Kg}$ di Kota Surabaya Dengan Mempertimbangkan Pertumbuhan Demand, Jurusan Teknik Industri, Institut Teknologi Sepuluh November (ITS), Surabaya.
Ni Putu Ayu Nariswari, (2009), Simulasi Penerapan Cosed System pada distribusi LPG 3 kg. Studi Kasus Distribusi LPG $3 \mathrm{~kg}$ Kec. Klojen Malang.Jurusan Teknik Industri, Institut Teknologi Sepuluh November (ITS), Surabaya.

Sofa. 2008. Teori Lokasi. Tersedia di http://massofa.wordpress.com Agustus 2008] 